\title{
A Missed Opportunity: Women and the 2010 UK General Election
}

\author{
Sarah Childs
}

\begin{abstract}
The 2010 UK general election presented a rare opportunity to significantly enhance women's representation in the UK due to the larger numbers of vacant-held seats following the parliamentary expenses scandal of 2009. However, despite encouraging words and commitments from the main political parties, the opportunity was missed. The proportion of women's representation in the UK parliament remains at around 22 per cent, comparing unfavourably with countries as diverse as Rwanda and Sweden, and leaving the UK ranking 52nd in the global league table. Although there is no one single answer for achieving sex parity in politics, many factors can increase women's opportunities. At the 2010 general election, only the Labour party adopted the strategy of 'equality guarantees'; the other two parties preferred 'equality rhetoric' and 'equality promotion'; the outcome of the general election demonstrated, once again, the efficacy of the Labour party's equality guarantees.
\end{abstract}

\section{Introduction}

An historically unprecedented 142 women MPs were elected to the British House of Commons on 6 May 2010. Of these, 81 are Labour, 48 Conservative, seven Liberal Democrat, one SNP and four represent parties in Northern Ireland. The election also saw the first Muslim women MPs in any party; the first black woman MP, and an 'out' lesbian MP in the Conservative Party. The Green Party also achieved their first ever MP in the UK Parliament, who is also a woman. The UK meets the European regional average of women in lower houses, and beats the world average of 19.1 per cent. Yet, at less than onequarter of the House of Commons, the UK ranks joint 52nd in the global league table, behind countries as diverse as Rwanda (56 per cent); Sweden (46 per cent); South Africa (45 per cent); Argentina (39 per cent) and Portugal (27 per cent). The overall increase in the number of women MPs at Westminster since the last general election in 2005 is also tiny - a net gain of only 2.5 per cent. And this, crucially, from a General Election where all the main parties were publicly committed to selecting greater numbers of women candidates - David Cameron

(Conservative Party Leader and now Prime Minister) made it a central tenet of the modernisation of the Conservative Party - and where the opportunity to select (and elect) more women was enhanced by many more MPs than usual standing down following the parliamentary expenses scandal of 2009.

\section{Factors which influence women's descriptive representation}

For those seeking sex parity at Westminster, the 2010 election is an opportunity missed. So, what went wrong? There appears to be no single answer for women's descriptive representation that holds for all times and places. Countries with widely differing economic, social, cultural and political structures can have similar numbers of women representatives and the reverse also holds true. However, there are a large number of hypotheses that purport to explain the variations in women's descriptive representation. These can be broken down into cultural, socioeconomic and political factors, as Box 1 summarises. None, in themselves, have been found to be sufficient. For example, Pippa Norris (2004) found that electoral system effects are strongest in post-industrial societies and weakest in developing countries, while the use of sex quotas in some countries in Africa, for example Rwanda, Mozambique and South Africa, help explain their position among the top ranked countries.

IDS Bulletin Volume 41 Number 5 September 2010 C 2010 The Author. Journal compilation ( Institute of Development Studies Published by Blackwell Publishing Ltd, 9600 Garsington Road, Oxford OX4 2DQ, UK and 350 Main Street, Malden, MA 02148, USA 


\section{Box 1 Hypotheses for women's descriptive representation}

Cultural factors which increase women's representation:

- An egalitarian culture

- A higher degree of secularisation

The length of time since women's enfranchisement and the longer the duration, the higher the proportion of women's representation.

Socioeconomic factors which increase women's representation:

- Greater participation of women in the public sphere

- Greater participation by women in the professions from which politicians are recruited

- A larger role by the state in both the public and private spheres (i.e. where the state is social democratic, rather than neoliberal), for instance provision of childcare enhances women's opportunities for political participation.

Political factors which increase women's representation:

- If the presence of proportional representation electoral systems increases, and the presence of majoritarian electoral systems decreases, this is because in majoritarian systems, the dynamic is to select the 'safest' candidate, i.e. the candidate who is most likely to win votes where the battle is between two parties in a narrow contest; in single-member constituencies, it is also a 'zero sum game' between women and men candidates, as only one candidate, either a male or a female candidate - can win

- A higher district magnitude (number of seats). This is because parties do not have to select between a woman or a man; and the absence of women makes a ticket look 'unbalanced'

- A higher party magnitude (number of parties competing in the electoral system). This is because of party competition

- The use of positive discrimination - well-designed and implemented sex quotas make a significant difference

- The presence of women (predisposed towards women's numerical representation) in top decision-making bodies within a party

- The more left-wing a party, the greater the likelihood of the selection of women as parliamentary candidates.

And in party democracies:

- The more centralised the party selection process, the greater the ability of party leaders, when willing, to encourage the selection of women as parliamentary candidates

- The higher the salience of the 'women's vote' to a particular party, the higher representation of women among that party's representatives. 


\section{Supply and demand issues}

In their groundbreaking study, Pippa Norris and Joni Lovenduski (1995) separate out four levels of analysis. At the first level are the systemic factors that set the broad context: the legal, electoral, party systems and the structure of party competition, the strength of parties, and the position of the parties across the ideological divide. The second level looks towards the context within parties - their organisation, rules and ideology. At the third level are the individual factors such as the resources and motivations of aspirant candidates, as well as the attitudes of the party selectorates. Finally, there are the individual elections that determine the outcome of the process for the composition of parliaments. In Britain, systemic factors are not significant inhibitors of women's descriptive representation. Women do not face legal barriers to their election, although the 'First Past the Post' (single member simple plurality, SMSP) majoritarian electoral system used for Westminster is widely considered to be less favourable for women candidates than proportional representation systems. (In a single member constituency the selectorate have only a single candidate to select and are likely to prefer a candidate that is similar to existing candidates.) Nonetheless, the recent increases in the number of women MPs have occurred during a period in which the electoral system has stayed constant. More important than the electoral system per se, then, is the acknowledgement that the overwhelming majority of MPs elected to the UK Parliament are representatives of political parties. In such contexts, the question of 'who our representatives are' is one of whom our political parties select as their candidates.

The outcome of particular political parties' selection processes is often understood in terms of the interaction between the supply of applicants wishing to pursue a political career and the demands of selectors who choose candidates on the basis of their preferences and perceptions of abilities, qualifications and perceived electability (Norris and Lovenduski 1995). Supply-side factors likely to limit the overall level of women seeking selection include gendered socialisation and the sexual division of labour. Women are, on average, likely to have fewer resources than men, whether that is the necessary free time to engage in politics, money to fund selection and election campaigns, and/or lower levels of political ambition, confidence and experience. On the demand-side, women have been found to suffer from selectorate discrimination, that is, a lack of party demand for women candidates (Shepherd-Robinson and Lovenduski 2002). This can take different forms. Direct discrimination refers to the positive or negative judgement of people on the basis of characteristics seen as common to their group, rather than as individuals; it reflects the attitudes of the selectors, and can be seen where gender discriminatory questions are posed during the selection process (Norris and Lovenduski 1995). Indirect discrimination refers to instances where the idea of what constitutes a 'good MP' count against women - where, for example, party selectorates prefer candidates with resources primarily associated with men and masculinity. Imputed discrimination is where party members may be unwilling to choose a woman candidate because they are concerned that by so doing they would lose votes. Here, the discrimination reflects what the selectors perceive to be the attitudes of the electorate.

The relative importance of supply- and demandside explanations for women's legislative recruitment at Westminster has varied over time and between political parties. Historically, it was said simply that there were an insufficient number of qualified women in the supply pool and as soon as greater numbers of women participated in the public sphere, especially in those professions such as law that constitute the recruiting grounds for politicians, then more women would seek political candidature. These women would, in turn, be selected by parties and, ultimately, elected as MPs. However, when women's participation in the public sphere did increase, and in the absence of a corresponding rise in the number of women MPs, the argument was transformed. The problem was now portrayed as a failure on behalf of qualified women to seek selection. This was said to be particularly true for some parties, namely the Conservative Party (Kittilson 2006: 2; Norris and Lovenduski 1995). Today, there is more of a consensus, at least among feminist political scientists, if not among all political actors, that the problem at Westminster is less one of supply and more one of demand.

This is not to suggest that gender and politics scholars should not be concerned about the size 
of the women's supply pool; nor seek to ensure diversity among women in that supply pool. The increasing professionalisation and narrowing of the UK political class is widely noted and rarely approved of. Nor does an acknowledgment that women are, on average, likely to have fewer resources than men, whether that is the free time to engage in politics (on top of working and caring for their families), money to fund their selection and election campaigns, less political ambition, confidence and experience, mean that reforms cannot be made to the culture and workings of politics. Political reforms can make this more 'women' and 'family' friendly: there could be better training, more chances of internships and better equal opportunities practices at Westminster. For example, the House could sit 'business hours'; there could be 'job-shares' for Ministers, if not MPs; maternity and paternity leave could be provided; and campaigning conduct could also be agreed between the parties. All of these changes acknowledge MPs' private lives to a much greater extent. And while creche facilities are in the process of being made available to MPs on the parliamentary estate, the new funding arrangements for MPs should also acknowledge women's greater responsibility for family life. Even so, and in the absence of many of these reforms, it needs to be restated that there are plenty of women aspirant candidates who already have the necessary resources and motivation; all of the parties have enough women seeking selection to select women for at least half of their held and/or winnable seats. At each election for the main two parties, we are probably talking about identifying just over 50 women, competent and capable of being an MP.

\section{Equality rhetoric, promotion and guarantees}

For the 2010 election, all the main three parties were publicly committed to increasing the diversity of their MPs and had expended considerable political capital on introducing and implementing a range of measures to that end. There are three main strategies available: equality rhetoric, equality promotion and equality guarantees, as Table 1 outlines. Equality rhetoric and promotion are widespread and largely uncontested in all of the main UK political parties, whereas the adoption of equality guarantees is both more limited and contested. Equality rhetoric consists of party statements, oral and written, that publicly acknowledge the claim for women's descriptive representation. It aims to exhort women to participate in party politics and to seek political candidature. Equality rhetoric can also help persuade party selectorates to choose women as candidates. Accordingly, equality rhetoric has the potential to impact on both the supply and demand sides of legislative recruitment, although it is more likely to impact on the former (Lovenduski 2005: 92). It also constitutes an opportunity around which gender equality advocates, inside and outside of parties, can mobilise.

Equality promotion measures attempt to bring those who are currently under-represented into political competition. It refers to a range of activities and measures that provide women with the necessary resources to successfully compete in the political recruitment process. As such, this approach is largely underpinned by supply-side arguments: women are regarded as deficient in the resources desired by party selectorates. The most widespread example of equality promotion is candidate training, something all the main UK political parties provide. Often, this is womenonly. The provision of training for women is, however, subject to three main criticisms. First, aspirant women candidates are known to declare that they, 'don't need any more training'; second, training women to compete according to the current rules of the recruitment game does little to unpack parties' assumptions about what makes a good candidate (Harrison 2006); and finally, training candidates may be insufficient to negate selectorate discrimination against women. Other equality promotion measures, such as the provision of financial assistance, take on greater significance where the cost of fighting party selections is high.

Equality promotion can also take the form of 'soft targets', for example Labour's intention to achieve a Parliamentary Labour party with 35 per cent women following the 2005 General Election. It can also refer to measures that, on first glance, look like equality guarantees, but whose finer details and/or implementation reveal that they fall short (Dahlerup and Freidenvall 2005). Measures that merely 'facilitate' or 'encourage' or 'expect' the greater selection of women remain examples of equality promotion, albeit strong forms. Party rules that set a minimum quota at the nominating or shortlisting stages of candidate selection have the potential to increase the 


\begin{tabular}{|c|c|c|c|}
\hline Type of strategy & Definition & Examples & Impact \\
\hline Equality rhetoric & $\begin{array}{l}\text { Public acceptance of } \\
\text { claims for representation }\end{array}$ & $\begin{array}{l}\text { Found in party campaign } \\
\text { platforms; party political } \\
\text { discourse; speeches and } \\
\text { writings of political leaders } \\
\text { (exhortation of women to } \\
\text { come forward and seek } \\
\text { selection) }\end{array}$ & $\begin{array}{l}\text { Affects selectorate and } \\
\text { aspirant candidates' attitudes } \\
\text { and beliefs }\end{array}$ \\
\hline Equality promotion & $\begin{array}{l}\text { Attempts to bring those } \\
\text { who are currently under- } \\
\text { represented into political } \\
\text { competition }\end{array}$ & $\begin{array}{l}\text { Special training; financial } \\
\text { assistance; the setting of } \\
\text { targets }\end{array}$ & $\begin{array}{l}\text { Enhances aspirant candidates' } \\
\text { resources and motivation; } \\
\text { affects selectorate attitudes }\end{array}$ \\
\hline Equality guarantees & $\begin{array}{l}\text { Requires an increase in } \\
\text { the number or proportion } \\
\text { of particular candidates; } \\
\text { makes a particular social } \\
\text { characteristic a necessary } \\
\text { qualification for office }\end{array}$ & $\begin{array}{l}\text { Party quotas, legislative } \\
\text { quotas; reserved seats, All } \\
\text { Women Shortlists (AWS) }\end{array}$ & $\begin{array}{l}\text { Creates an artificial demand; } \\
\text { may increase supply }\end{array}$ \\
\hline
\end{tabular}

Source Childs et al. (2005), citing Lovenduski (2005).

numbers of women selected but this does not guarantee that they will. Nor do they guarantee that any selected women candidates will be subsequently elected. Qualitatively distinct, equality guarantees require an increase in the number or proportion of particular parliamentarians and/or make a particular social characteristic a necessary qualification for office (following Lovenduski 2005: 90-1, with emphasis added). Importantly, equality guarantees create an artificial demand, although they may also indirectly encourage an increase in the supply of women, as women perceive a new demand on behalf of a particular political party.

The distinction between equality promotion and equality guarantees can be further clarified through considering the implementation of Labour's All Women Shortlists (AWS). In 1997, 2005 and 2010, Labour employed AWS in a proportion of its vacant-held seats and winnable seats. This strategy means, first, that all candidates seeking selection in these particular constituencies are women. Second, because the selected candidate is contesting a Labour-held or winnable seat, she should - all other things being equal - be elected as an MP.

For the 2010 UK general election, all the main political parties encouraged women to come forward and helped them become candidates, not least through training and mentoring - engaging in both equality rhetoric and equality promotion. In respect of the latter, the Liberal Democrats had a sex-quota at the shortlisting stage of selection: shortlists of three or four must have at least one applicant of each sex; shortlists of five must have at least two applicants of each sex. Where necessary, the list would be increased rather than decreased to conform to the gender balance, provided all applicants meet the minimum standards. The Conservatives introduced a series of reforms, including the creation of a priority list of candidates (A list), of which 50 per cent would be female, the greater use of primaries and a 50:50 sex quota at the shortlisting stage. All of these measures increased the chances that more women would come in front of those who choose parliamentary candidates. But both the Liberal Democrats and the Conservative parties rejected the logic of equality guarantees, no doubt because of party ideology (not least ideas of merit) and local party autonomy. Despite Cameron's apparent, and belated, embracing of AWS for some post-January 2010 selections, there were none. Moreover, Conservative AWS would have been happenstance rather than an example of an 'equality guarantee'; using the party's by-election rules the 'three' candidates from whom a local association would select would just happen to be 


\section{Box 2 Speaker's conference recommendations: select}

23. We fully support the proposed extension of the Sex Discrimination (Election Candidates) Act 2002 to enable the use of all-women shortlists until 2030.

24. If the political parties fail to make significant progress on women's representation at the 2010 general election, Parliament should give serious consideration to the introduction of prescriptive quotas, ensuring that all political parties adopt some form of equality guarantee in time for the following general election.

25. We recommend that all political parties registered under part 2 of the Political Parties, Elections and Referendums Act 2000 should be required to publish details of their candidate selections online every seven months, on 31 March and 31 October, setting out, for each potential candidate at each stage of the selection process, the following information: (a) the administrative region in which the selection took place; (b) the method by which the candidate was selected; (c) whether the party: (i) currently holds the seat for which the candidate was selected; or (ii) came second or third in the seat at the last general election within a margin of less than 5 per cent of the votes cast; or (iii) came second or third in the seat at the last general election within a margin of more than 5 per cent but less than 10 per cent of the votes cast; (d) the sex of the candidate; (e) the ethnicity of the candidate; and (f) whether the candidate is willing to identify as a disabled person. The reports might also include the following information: (a) where a candidate is willing to identify as a disabled person, the nature of the impairment; (b) where a candidate is willing to state his or her sexual orientation, the sexual orientation of the candidate; (c) the age of the candidate; (d) the occupation of the candidate at the time of selection; and (e) the highest level of the candidate's educational attainment.

26. We recommend that the Government should find time for a debate on the implementation of the Speaker's Conference's recommendations and progress towards just Representation in the House of Commons in 2010, 2012, and every two years thereafter, to 2022.

Source: House of Commons (2010) Speaker's Conference (On Parliamentary Representation), HC 329-1.

all women. In contrast, the Labour party adopted once again equality guarantees - measures designed to require that women are selected.

So what difference did the various equality strategies and the extra effort make this time around? The numbers of Liberal Democrat women MPs declined from nine to seven, as the electoral swing went against them; the Labour party's total of women MPs fell too, by 17, from 98 to 81 (31 per cent of their parliamentary party); only the Conservatives increased their number - more than doubling to 48, from 17 (16 per cent of their parliamentary party). A welcome increase, but Conservative gains fall short of their expectation of some 60 women MPs. And notwithstanding these developments, the interparty asymmetry in women's descriptive representation, in Labour's favour, at Westminster remains. And in those 2010 retirement seats - the unexpected seats freed up by the parliamentary expenses scandal, and which, all other things being equal, a party is likely to hold - the percentage of women selected by the Conservatives was only 26 per cent compared with Labour's 53 per cent. Here Labour's use of AWS delivered. Used in more than half of its retirement seats, all of the 23 Labour women candidates selected on AWS made it to the Commons. Hence, at a general election where Labour lost nearly 100 seats, the percentage of its women MPs actually increased, to a high of 31 per cent from 28 per cent, without a very large loss in the number of its women MPs. Once again, party demand - equality guarantees operationalised through AWS - looks critical. 


\section{Conclusion}

In the months and years to come, women's descriptive representation at Westminster must not be allowed to fall off the political agenda. There are already, in the first Queen's Speech of the coalition government, legislative plans to reduce the number of seats in the House of Commons. This will see sitting MPs fighting it out against each other for their party's selection; women MPs must not be a casualty of this reform. And if there is to be electoral system reform, its impact on the selection and election of women must also be addressed. Comparative studies reveal that some systems of proportional representation are more favourable to women's election than others. Disconcertingly, there is not much sign that gender concerns like these are in the minds of those within the Government who will lead on these reforms. Theresa May, the new Conservative Home Secretary and Minister for Women and Equality, and her Liberal Democrat Parliamentary Under Secretary of State (Minister for Equalities) for the Home Office, Lynne Featherstone, will need to take this up with the Deputy Prime Minister and Liberal Democrat Leader, Nick Clegg. And it is not as if the issue of women's descriptive representation has not been on the parliamentary agenda. A Speaker's Conference ${ }^{1}$ was established in 2007 to

\section{Notes}

* This article draws upon and updates Childs (2008).

\section{References}

Childs, S. (2008) Women and British Party Politics, London: Routledge

Childs, S.; Lovenduski, J. and Campbell, R. (2005) Women on Top, London: Hansard Society

Dahlerup, D. and Freidenvall, L. (2005) 'Quotas as a Fast Track to Equal Political Representation for Women: Why Scandinavia is no Longer the Model', International Feminist Journal of Politics 7.1: 26-48

Harrison, L. (2006) 'Women's Legislative Representation - Do Political Parties Utilize a Gendered Model of the "Good Candidate", unpublished paper consider the important issue of the representation of women and ethnic minorities in the House of Commons. Recommendations reported before the 2010 general election included, inter alia, that parties publish their selection data and Parliament routinely debates their progress (see Box 2).

Most importantly, although as yet apparently unrecognised by the Government or the media, Recommendation 24 suggests that Parliament should 'give serious consideration' to prescriptive rather than permissive quotas if 'significant' progress is not made at the 2010 general election - and there was no significant progress in 2010. Supporters of women's political representation, inside and outside of parties and parliament, should mobilise now to ensure that the missed opportunity of 2010 is not only fully appreciated but that pressure is placed on all the party leaders (including the future Labour leader, as yet unknown at the time of writing) and on the government and parliament to make good on their commitment to adequately feminise the House of Commons. At less than one-quarter of all members of the UK parliament, women's descriptive representation remains, as before, far from parity.

1 Speakers Conferences consider issues of electoral law and constitutional reform.

Kittilson, M.C. (2006) Challenging Parties, Changing Parliaments, Columbus: Ohio State University Press

Lovenduski, J. (2005) Feminizing Politics, Cambridge: Polity

Norris, P. (2004) Electoral Engineering, Cambridge: Cambridge University Press

Norris, P. and Lovenduski, J. (1995) Political Recruitment, Cambridge: Cambridge University Press

Shepherd-Robinson, L. and Lovenduski, J. (2002) Women and Candidate Selection, London: Fawcett Society 